MELO, RAC; JORGE, MHA; BORTOLIN, A; BOITEUX, LS; RIBEIRO, C; MARCONCINI, JM. 2019. Growth of tomato seedlings in substrates containing a nanocomposite hydrogel with calcium montmorillonite (NC-MMt). Horticultura Brasileira 37: 199-203. DOI - http://dx.doi.org/10.1590/ S0102-053620190210

\title{
Growth of tomato seedlings in substrates containing a nanocomposite hydrogel with calcium montmorillonite (NC-MMt)
}

\section{Raphael AC Melo ${ }^{1} \mathbb{D}$; Marçal HA Jorge ${ }^{1} \mathbb{D}$; Adriel Bortolin ${ }^{2} \mathbb{D}$; Leonardo S Boiteux ${ }^{1} \mathbb{D}$; Caue Ribeiro² $\mathbb{D}$; José M Marconcini ${ }^{2} \mathbb{D}$}

1Embrapa Hortaliças, Brasília-DF, Brazil; raphael.melo@embrapa.br; marcal.jorge@embrapa.br; leonardo.boiteux@embrapa.br; ${ }^{2} E m b r a p a$ Instrumentação, São Carlos-SP, Brazil; caue.ribeiro@embrapa.br; jose.marconcini@embrapa.br; adrielbortolin@gmail.com

\begin{abstract}
The correct use of hydrogels in some situations can increase seedling survival rates, plant growth, and the water-retention capacity of the growing medium. A technique for the production of a nanocomposite hydrogel using calcium montmorillonite (NCMMt) was recently developed. However, additional research is necessary in order to validate this innovative input, particularly for the production of vegetable crops seedlings. In this context, the main objective of the present study was to evaluate the growth and development of seedlings, tomato hybrid 'BRS Nagai', in substrates containing different amendments of hydrogel NC-MMt. The trial was conducted in a $3 \times 3$ factorial arranged in a complete randomized blocks design, with three replications. Three substrates (peat moss, pine bark, and coconut peat) corresponded to the first factor and three rates of the NC-MMt hydrogel $(0 \%=\mathrm{R} 1,1.5 \%=\mathrm{R} 2$ and $2.0 \%=\mathrm{R} 3$, on a w/w basis) corresponded to the second factor. Each plot was composed of 16 plants that were assessed after three weeks. Overall, peat moss-based and pine bark-based substrates resulted in higher values for most of the analyzed traits: plant emergency percentage, plant height, stem diameter, leaf area, plant height/shoot dry weight ratio, root dry weight, shoot dry weight/root dry weight ratio and the Dickinson Quality Index. Rates of NC-MMt hydrogel displayed significant responses only to root superficial area and root volume. NC-MMt hydrogel amendment (mainly $1.5 \%$ ) combined with specific substrates (mainly peat moss-based substrate) was able to improve the growth of 'BRS Nagai' tomato seedlings, with no observed toxic effects.
\end{abstract}

Keywords: Solanum lycopersicum, plantlet, hydrophilic polymer.

\section{RESUMO}

Crescimento de mudas de tomateiro em substratos contendo hidrogel nanocompósito com montmorilonita de cálcio (NC-MMt)

O uso correto de hidrogéis em determinadas situações pode aumentar as taxas de sobrevivência das plântulas, seu crescimento e a capacidade de retenção de água do meio de cultivo. Uma técnica para a produção de um hidrogel nanocompósito usando montmorilonita de cálcio (NC-MMt) foi desenvolvida recentemente. No entanto, resultados da pesquisa ainda são necessários para validar este insumo inovador, particularmente para a produção de mudas de hortaliças. Neste contexto, o principal objetivo do presente estudo foi avaliar o crescimento e desenvolvimento de mudas do híbrido de tomate 'BRS Nagai' em substratos contendo diferentes dosagens do hidrogel NC-MMt. O experimento foi conduzido em arranjo fatorial 3x3, em delineamento de blocos ao acaso, com três repetições. Os substratos (turfa, casca de pinheiro, e fibra de coco) corresponderam ao primeiro fator e três dosagens de hidrogel NC-MMt $(0 \%, 1,5 \%$ e $2,0 \%$, base peso/peso) corresponderam ao segundo fator. Cada parcela foi composta por 16 plantas que foram utilizadas para avaliação dos tratamentos após três semanas. No geral, turfa e casca de pinheiro promoveram maiores valores para a maioria das variáveis analisadas; percentual de emergência, altura de planta, diâmetro de caule, área foliar, relação altura da planta/peso seco, peso seco de raízes, relação peso seco da parte aérea/peso seco de raízes e Índice de Qualidade de Dickinson. As dosagens de hidrogel NC-MMt responderam significativamente apenas à área superficial da raiz e ao volume radicular. O fornecimento de hidrogel NC-MMt (principalmente a dosagem de $1,5 \%$ ) combinado com substratos específicos (principalmente turfa) demonstrou melhorar o crescimento de mudas do tomateiro BRS Nagai, com ausência de efeitos fitotóxicos.

Palavras chave: Solanum lycopersicum, plântula, polímero hidrofílico.

\section{Received on May 25, 2018; accepted on January 15, 2019}

$\mathrm{H}$ ydrogels are becoming important agricultural inputs due to a set of agronomic properties such as nontoxicity, biodegradability, sources of nutrients, and soil pH stabilizers (Sabadini, 2015). In addition, hydrogels have high water-retention capability, displaying a sustained ability to release water and fertilizers (Sabadini, 2015).
The early 1980s was the turning point of the experimentation with hydrogels as soil conditioners for vegetable production, with several studies being conducted with a wide range of crops. Willingham \& Coffey (1981) observed substantial improvements in the production of tomato (Solanum lycopersicum) following the amendment of hydrophilic polymers. Wofford Junior (1989) observed, under sandy soil conditions, average tomato yields of 40 $t$ ha $^{-1}$ in plots treated with cross-linked polyacrylamide, inducing significant increases when compared to the control plots $\left(27 \mathrm{tha}^{-1}\right)$.

However, it is essential to highlight that effectiveness of these hydrophilic 
polymers might vary depending upon the transplanting condition as well as the properties of the growth medium. One major constraint is the overall low level of mechanical resilience of the commercially available hydrogels $(\mathrm{Du}$ et al., 2014). To solve this problem, investigations with nanocomposite hydrogels (NC) were intensified in the last two decades and new methods for manufacturing hydrogels with improved mechanical resilience were achieved (Du et al., 2014). This new generation of cross-linked hydrogels (commonly named "smart hydrogels") displays remarkable water-retention properties and they can withstand large variations in temperature, $\mathrm{pH}$, and ionic strength of the swelling solution (Anupama et al., 2007). However, there is a pressing need to explore alternative water-retention technologies for employment in warm tropical and subtropical climates due to poor water and nutrient use efficiency in these geographical areas (Anupama et al., 2007).

An innovative technique for $\mathrm{NC}$ production using calcium montmorillonite (MMt) allowed the development of a new class of hydrogels with great swelling degree (higher than 2,000 times in water) (Bortolin et al., 2016). This new NC is formulated with a high content of MMt $(\approx 50 \%$ wt) and it has high loading capacity and displays slow release of macro- as well as micronutrients when they are incorporated in the hydrogel synthesis or through fertigation (Bortolin et al., 2016). Therefore, this NC-MMt hydrogel may represent an interesting crop management tool, which could be suitable for a wide array of agricultural applications (Bortolin et al., 2016).

To date, no research has been conducted to study the application of a nanocomposite hydrogel for tomato seedlings production in substrates. Previous works, with other plant species, are restricted to the use of hydrogel under field conditions when it is incorporated into soil aiming to increase yield or to overcome abiotic stresses in different crops such as cauliflower (Castoldi et al., 2016), chickpea (Akhter et al., 2004), chrysanthemum (Anupama et al., 2007), coffee (Lima et al.,
2003; Franchement, 2012), eucalyptus (Sanches, 2013), lettuce (Santos et al., 2015) and poinsettia (Wang, 1992).

Studies on hydrogel employment for the production of vegetable crop seedlings are imperative given the economic importance of this activity under Brazilian conditions. In 2016, a total of US\$ 18.68 million profit was obtained with the commercialization of tomato seedlings (Confederação..., 2017). Given this significance, novel technologies should be adopted and new inputs made available aiming to produce vegetable seedlings with superior quality (Jorge et al., 2016). In this context, the main objective of the present study was to evaluate the growth and development of tomato seedlings in commercial substrates containing different amendments of a novel hydrogel (NC-MMt).

\section{MATERIAL AND METHODS}

\section{Site of experimentation}

The experiment was conducted under protected environment conditions (April 2016) at Embrapa Hortaliças ( $15^{\circ} 56^{\prime} \mathrm{S}$, $48^{\circ} 08^{\prime} \mathrm{W}, 996 \mathrm{~m}$ altitude), Brasília-DF, Brazil. The assay was established in a greenhouse, $25 \mathrm{~m}$ long, $8 \mathrm{~m}$ wide, and $2.5 \mathrm{~m}$ height, covered with a 150 -micron low-density polyethylene film. During the period of the trial, inside temperature and humidity were measured daily (9 $\mathrm{AM}, 12 \mathrm{AM}$, and $3 \mathrm{PM}$ ). During the assay, temperature mean values were $22.3^{\circ} \mathrm{C}$, minimum $21.7^{\circ} \mathrm{C}$ and $23^{\circ} \mathrm{C}$ maximum. The mean relative humidity value was $73 \%$ (minimum $31 \%$ and maximum 94\%). Mean global solar radiation during the period was 17

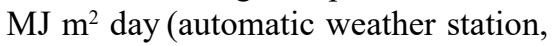
Gama-DF), Brazilian National Institute of Meteorology (Inmet).

\section{Seedling production}

Seedlings were produced in 200-cell plastic trays $\left(\mathrm{JKS}^{\circledR}, 12.5 \mathrm{~cm}^{3}\right.$ per plug). The tomato hybrid 'BRS Nagai' (with $90 \%$ expected germination according to label information) was selected due to its wide geographic adaptation and its good agronomic/horticultural performance across distinct Brazilian geographic regions (Embrapa, 2014). After that, trays were filled with substrate and seeds were planted (one seed per plug) at $6 \mathrm{~mm}$ depth. For watering, the critical low moisture limit of the substrates was standardized at $20 \%$ of their water retention capacity. Trays were weighed at daily basis in order to determine the rate of water loss and followed by $100 \%$ replacement of the water volume consumed by the crop. The hydrogel releases water to plants only at low matric potentials (Heiskanen, 1995).

\section{Treatments and experimental} design

The trial was conducted in $3 \times 3$ factorial arrangement in complete randomized blocks design, with three replications. Three distinct soilless commercial substrates (commonly used in the Brazilian seedling industry) were employed, which corresponded to the first factor: peat moss-based $\left(\right.$ Carolina Padrão $\left.{ }^{\circledR}\right)$; pine bark-based $\left(\right.$ Rohrbacher $\left.^{\circledR}\right)$; coconut peat-based (Golden Mix $^{\circledR}$ ). Carolina Padrão ${ }^{\circledR}$ substrate displayed the following characteristics: $\mathrm{EC}=0.4 \pm 0.3 \mathrm{mS} \mathrm{cm}{ }^{-1}$; $\mathrm{pH}=5.5$; water holding capacity $=$ $55 \%$; humidity $=50 \%$; and density $=145 \mathrm{~kg} \mathrm{~m}^{-3}$. Rohbacher ${ }^{\circledR}$ substrate displayed the following characteristics: $\mathrm{EC}=0.4 \pm 0.3 \mathrm{mS} \mathrm{cm}^{-1} ; \mathrm{pH}=6.0$; water holding capacity $=50 \%$; humidity $=$ $60 \%$; and density $=185 \mathrm{~kg} \mathrm{~m}^{-3}$. Golden $\mathrm{Mix}^{\circledR}$ substrate displayed the following characteristics: $\mathrm{EC}=0.7 \mathrm{mS} \mathrm{cm}-1, \mathrm{pH}=$ 6.0 ; water holding capacity $=50.7 \%$; humidity $=50 \%$; and density $=150$ $\mathrm{kg} \mathrm{m}^{-3}$.

Nc-MMt hydrogel was synthesized utilizing PAAm (polyacrylamide compression) and biodegradable polysaccharide CMC (carboxymethyl cellulose) with molecular weight $=$ 90,000 $\mathrm{g} \mathrm{mol}^{-1}, 0.7$ carboxymethyl groups per anhydroglucose unit (data provided by Sigma-Aldrich). Components were formulated through chemical polymerization of acrylamide monomers (AAm, Sigma-Aldrich) in an aqueous solution containing $\mathrm{CMC}$ and MMt $\left[\mathrm{Ca}_{0.6}(\mathrm{Al}, \mathrm{Mg})_{2} \mathrm{Si}_{4} \mathrm{O}_{10}(\mathrm{OH})_{2} \cdot n \mathrm{H}\right.$ $\left.{ }_{2} \mathrm{O}\right)$ ]. The final composition of hydrogel was $[\mathrm{AAm}+\mathrm{CMC}]): m(\mathrm{MMt})$ ratio (i.e., hydrogel mass per unit mass of clay) of 1:1. In this sense, the hydrogel $(1: 1)$ contains $\approx 50 \%$ MMt (Bortolin et 
$a l ., 2016)$. Three rates of hydrogel NCMMt (on w w ${ }^{-1}$ basis) were employed; they corresponded to the second factor, being: $0 \%$ (control), $1.5 \%$ and $2.0 \%$.

These amounts of hydrogel NCMMt employed in the present study followed the recommendations derived from previous assays (Bortolin et $a l ., 2016)$ and are in agreement with the quantities reported in literature for other vegetable crops such as cauliflower (Castoldi et al., 2016). Stirring procedure was carried out using plastic bags (one homogenate for each treatment) done a day before sowing. Each plot was composed of 16 plants per tray, four rows with four plugs containing one plant each.

\section{Measured parameters}

All morphological plant traits were evaluated 21 days after sowing (DAS). The following set of parameters associated with tomato seedling development was evaluated: Seeds emergence [plant emergency percentage was measured 7 and 14 days after sowing (DAS) according to the Brazilian Rules to Seeds Analysis (BRASIL, 2009)]; Plant's aerial parts [plant height and stem diameter, measured using a digital pachymeter (Mitutoyo ${ }^{\circledR}$ Absolute 700113-10)]; Number of leaves (NL) and leaf area (LA, in $\left.\mathrm{cm}^{2}\right)$ [obtained using Image J software (Glozer, 2008)]; Plant's root system [root volume, root superficial area and average root diameter, measured in $\mathrm{mm}^{3}, \mathrm{~mm}^{2}$, and $\mathrm{mm}$, respectively, using SAFIRA image processing software (Jorge \& Rodrigues, 2008)]. Plants aerial and root parts were separated and dehydrated under electric oven conditions until constant weight reached after 72 hours at $65^{\circ} \mathrm{C}$; to obtain shoot dry weight and root dry weight, $(\mathrm{mg})$, a precision scale $(0.001 \mathrm{~g})$ was used. Plant height/shoot dry weight and shoot dry weight/root dry weight ratios were determined using a precision scale $(0.001 \mathrm{~g})$. The Dickson Quality Index was also calculated using the equation: Total dry weight $(\mathrm{g}) /$ pplant height $(\mathrm{cm}) /$ stem diameter $(\mathrm{mm})+$ shoot dry weight (g) / root dry weight $(\mathrm{g})\}$.

Tests for normality and homogeneity were performed with all the dataset. Preliminary analyses indicated that shoot dry weight, root volume, root superficial area, and the Dickson Quality Index had skewed and overdispersed distributions. Therefore, a square root transformation was required to use in order to normalize the data. Normality of residuals was tested using ShapiroWilk test $(\alpha=5 \%)$ and, subsequently, displayed as normal distributions. Analyses of variance were carried out using the software Assistat ${ }^{\circledR}$ (Silva \& Azevedo, 2016) and Tukey's multiple range tests were conducted on the gathered data.

\section{RESULTS AND DISCUSSION}

Analysis of variance indicated no significant interaction $(\mathrm{P}>0.05)$ among the factors hydrogel rates and substrate types. Overall, there were significant effects of the substrate types on the analyzed variables, except on the PE 7 DAS, NL, RV and ARD. Significant effects of the hydrogel rates were observed only on the SD, RSA and RV.

Regarding the plant emergency percentage, coconut peat-based and peat moss-based substrates at 14 DAS, reached $89.4 \%$ and $88.9 \%$ respectively, differing from pine bark based substrate (Table 1). Although pine bark may contain substances such as terpenoids, which can have adverse effects on plant growth (Maher et al. 2008) in conjunction with hydrogel that may cause physical restrictions to the growing media (Fonteno \& Bilderback, 1993), all observed seed germination values were considered within the standards and close to the label information (90\% germination), not limiting plant development afterwards.

In terms of plant height, values of $68.85 \mathrm{~mm}$ were observed for peat moss-based substrate, differing from the other substrates (Table 1). Peat has high porosity, providing good soil aeration and improved water-holding capacity (Maher et al., 2008). These characteristics might be associated with this significant response of this substrate. Also, low $\mathrm{pH}$ and nutrient content of peat make it easy to supplement lime and fertilizers through fertigation (Maher et al., 2008). In fact, the employed commercial substrate (Carolina Padrão ${ }^{\circledR}$ ) is composed of a mix of peat, lime, and fertilizers. All obtained values are considered an adequate tomato seedling height. Luna $e t$ al. (2014) stated that seedlings above 15 $\mathrm{cm}$ are not desirable, since the wind can break their stem at the transplantation. A similar response was observed for shoot diameter using peat moss-based and pine bark-based substrates displaying superior values when compared to coconut peat-based substrate. Shoot diameter is a trait associated with vigorous plants, representing lower probability of seedlings to bend during transplantation (Luna et al., 2014).

Pine bark based and coconut peatbased substrates presented higher leaf area values compared to peat moss-

Table 1. Means of plant emergence (\%) (PE) 7 and 14 days after sowing (DAS), plant height $(\mathrm{mm})(\mathrm{PH})$, shoot diameter $(\mathrm{mm})(\mathrm{SD})$, leaf area $\left(\mathrm{cm}^{2}\right.$ plant $\left.{ }^{-1}\right)(\mathrm{LA})$, and number of leaves $(\mathrm{NL})$ among substrates and hydrogel rates, measured 21 DAS. Brasília, Embrapa Hortaliças, 2016.

\begin{tabular}{|c|c|c|c|c|c|c|}
\hline \multirow{2}{*}{$\begin{array}{l}\text { Factor } \\
\text { levels }\end{array}$} & \multicolumn{2}{|c|}{ PE (\%) } & \multirow{2}{*}{$\begin{array}{c}\text { PH } \\
(\mathbf{m m})\end{array}$} & \multirow{2}{*}{$\begin{array}{c}\text { SD } \\
(\mathbf{m m})\end{array}$} & \multirow{2}{*}{$\begin{array}{l}\mathbf{L A}\left(\mathbf{c m}^{2}\right. \\
\left.\text { plant }^{-1}\right)\end{array}$} & \multirow{2}{*}{ NL } \\
\hline & 7 DAS & 14 DAS & & & & \\
\hline \multicolumn{7}{|c|}{ Substrates } \\
\hline $\mathrm{T} 1$ & $88.4 \mathrm{a}$ & $88.9 \mathrm{ab}$ & $68.85 \mathrm{a}$ & $2.25 \mathrm{a}$ & $17.55 \mathrm{~b}$ & $12.00 \mathrm{a}$ \\
\hline $\mathrm{T} 2$ & $83.9 \mathrm{a}$ & $84.9 \mathrm{~b}$ & $59.84 \mathrm{~b}$ & $2.22 \mathrm{a}$ & $21.72 \mathrm{a}$ & $12.44 \mathrm{a}$ \\
\hline $\mathrm{T} 3$ & $88.3 \mathrm{a}$ & $89.4 \mathrm{a}$ & $61.09 \mathrm{~b}$ & $1.92 \mathrm{~b}$ & $19.51 \mathrm{a}$ & $11.78 \mathrm{a}$ \\
\hline \multicolumn{7}{|c|}{ Hydrogel rates (\%) } \\
\hline 0 & $88.33 \mathrm{a}$ & $89.26 \mathrm{a}$ & $61.21 \mathrm{a}$ & $2.03 \mathrm{~b}$ & $19.01 \mathrm{a}$ & $12.00 \mathrm{a}$ \\
\hline 1.5 & $83.52 \mathrm{a}$ & $86.48 \mathrm{a}$ & $64.00 \mathrm{a}$ & $2.22 \mathrm{a}$ & $20.56 \mathrm{a}$ & $12.56 \mathrm{a}$ \\
\hline 2.0 & $84.81 \mathrm{a}$ & $86.85 \mathrm{a}$ & $64.57 \mathrm{a}$ & $2.13 \mathrm{ab}$ & $19.22 \mathrm{a}$ & $11.72 \mathrm{a}$ \\
\hline
\end{tabular}

$\mathrm{T} 1=$ peat moss based Carolina Padrão ${ }^{\circledR} ; \mathrm{T} 2=$ pine bark based Rohrbacher $^{\circledR} ; \mathrm{T} 3=$ coconut peat based Golden $\mathrm{Mix}^{\circledR}$. Means followed by same letters in the columns do not differ by Tukey test, $5 \%$. 
based substrate, with $21.72 \mathrm{~cm}^{2}$ plant $^{-1}$ and $19.51 \mathrm{~cm}^{2}$ plant $^{-1}$, respectively (Table 1). There are no differences between substrates as regards the number of leaves. Leaf area and number of leaves are plant traits that provide directly the information about the right time for seedling transplant and, indirectly, indicate the photosynthetic capacity of the seedlings. Shoot dry weight reached $0.128 \mathrm{~g} \mathrm{plant}^{-1}$ in the peat moss-based substrate, not differing from pine bark based treatment, a ratification that this assimilation resulted in higher biomass value (Table 2).

Root dry weight of 0.038 g plant $^{-1}$ and Dickson Quality Index (DQI) of 0.0049 were also significantly responsive for the pine bark-based substrate, not differing from peat moss-

Table 2. Means of shoot dry weight (g plant-1) (SDW), root dry weight (g plant-1) (RDW), plant height (PH)/shoot dry weight (SDW) ratio, shoot dry weight (SDW)/root dry weight (RDW) ratio, and Dickson's Quality Index (DQI), among substrates and hydrogel rates, measured 21 DAS. Brasília, Embrapa Hortaliças, 2016.

\begin{tabular}{lccccc}
\hline Factor levels & $\begin{array}{c}\text { SDW } \\
\left(\text { g plant }^{-1}\right)\end{array}$ & $\begin{array}{c}\text { RDW } \\
\left.\text { (g plant }^{-1}\right)\end{array}$ & PH/SDW & SDW/RDW & DQI \\
\hline Substrates & & & & & \\
\hline $\mathrm{T} 1$ & $0.087 \mathrm{~b}$ & $0.032 \mathrm{ab}$ & $3.065 \mathrm{a}$ & $3.464 \mathrm{a}$ & $0.0040 \mathrm{ab}$ \\
$\mathrm{T} 2$ & $0.128 \mathrm{a}$ & $0.038 \mathrm{a}$ & $2.699 \mathrm{~b}$ & $3.293 \mathrm{a}$ & $0.0049 \mathrm{a}$ \\
$\mathrm{T} 3$ & $0.094 \mathrm{~b}$ & $0.028 \mathrm{~b}$ & $3.180 \mathrm{a}$ & $2.719 \mathrm{~b}$ & $0.0035 \mathrm{~b}$ \\
\hline \multicolumn{7}{l}{ Hydrogel rates (\%) } & & & & \\
\hline 0 & $0.095 \mathrm{a}$ & $0.034 \mathrm{a}$ & $3.01985 \mathrm{a}$ & $2.8737 \mathrm{a}$ & $0.0039 \mathrm{a}$ \\
1.5 & $0.108 \mathrm{a}$ & $0.033 \mathrm{a}$ & $2.87728 \mathrm{a}$ & $3.2437 \mathrm{a}$ & $0.0044 \mathrm{a}$ \\
2.0 & $0.106 \mathrm{a}$ & $0.032 \mathrm{a}$ & $3.04830 \mathrm{a}$ & $3.3592 \mathrm{a}$ & $0.0041 \mathrm{a}$ \\
\hline
\end{tabular}

T1= peat moss based Carolina Padrão ${ }^{\circledR} ; \mathrm{T} 2=$ pine bark based Rohrbacher $\AA$; $\mathrm{T} 3=$ coconut peat based Golden Mix ${ }^{\circledR}$. Means followed by same letters in the columns do not differ by Tukey test, $5 \%$.

Table 3. Means of root superficial area $\left(\mathrm{mm}^{2}\right.$ plant $\left.^{-1}\right)(\mathrm{RSA})$, root volume $\left(\mathrm{mm}^{3} / \mathrm{plant}^{-1}\right)(\mathrm{RV})$, average root diameter ( $\mathrm{mm}$ ) (ARD) and stem diameter (mm) (SD), among substrates and hydrogel rates, measured 21 DAS. Brasília, Embrapa Hortaliças, 2016.

\begin{tabular}{lccc}
\hline Factor levels & $\begin{array}{c}\text { RSA } \\
\left(\mathbf{m m}^{\mathbf{2}} \mathbf{p l a n t}^{-1}\right)\end{array}$ & $\begin{array}{c}\mathbf{R V} \\
\left(\mathbf{m m}^{\mathbf{3}} \mathbf{p l a n t}^{-1}\right)\end{array}$ & $\begin{array}{c}\text { ARD } \\
\left(\mathbf{m m}^{\mathbf{1}} \mathbf{\text { plant }} \mathbf{1}^{-1}\right)\end{array}$ \\
\hline Substrate & & & \\
\hline $\mathrm{T} 1$ & $27.17 \mathrm{ab}$ & $0.622 \mathrm{a}$ & $0.267 \mathrm{a}$ \\
$\mathrm{T} 2$ & $33.33 \mathrm{a}$ & $0.509 \mathrm{a}$ & $0.265 \mathrm{a}$ \\
$\mathrm{T} 3$ & $22.41 \mathrm{~b}$ & $0.327 \mathrm{a}$ & $0.190 \mathrm{a}$ \\
\hline Hydrogel rates & & & \\
\hline $0 \%$ & $19.58 \mathrm{~b}$ & $0.267 \mathrm{~b}$ & $0.190 \mathrm{a}$ \\
$1.5 \%$ & $27.42 \mathrm{ab}$ & $0.724 \mathrm{a}$ & $0.244 \mathrm{a}$ \\
$2.0 \%$ & $35.91 \mathrm{a}$ & $0.468 \mathrm{a}$ & $0.287 \mathrm{a}$ \\
\hline
\end{tabular}

Means followed by same letters in the columns do not differ by Tukey test, $5 \%$.
The application of a porous medium coupled to an image analysis system (Suchoff et al., 2017) was successfully employed as a tool to evaluate root morphology of tomato seedlings cultivated in distinct substrates. Rot dry weight, shoot dry weight/rot dry weight ratio, root superficial area, root volume, and average root diameter of each treatment were evaluated as indicators of seedling development and quality status, being used to describe the ratio of the morphological benefit to metabolic cost in root system development (Oztekin et al., 2009). Root dry weight in the pine bark-based substrate treatment differed from coconut peat-based substrate (Table 2). Root superficial area and root volume were affected by the rates (Table 3). For root superficial area, the $2.0 \%$ NC-MMt hydrogel rate was significantly different from control $(0 \%)$. For root volume, $1.5 \%$ and $2.0 \%$ NC-MMt hydrogel rates were different from control (Table 3). No differences were found for average root diameter as well as for NC-MMt hydrogel rates for both substrates (Table 3).

Seedlings having strong root system and greater stem diameter are more likely to overcome, after transplanting, the negative effects of drought, low soil temperatures, soil compaction, and air humidity (Grossnickle, 2005). The balance between root development and water/nutrient availability will have direct effects on stress tolerance. When several stresses overlap coincidentally, various responses would interact with each other and, hence, the volume of roots can be a crucial element (Nakano, 2007). So, a new set of studies will be required to evaluate the use of NC-MMt hydrogel in tomato seedlings for field production as a potential input for the management of abiotic stresses in this vegetable crop.

In conclusion, supplying NC-MMt hydrogel (at $1.5 \%$ rate) combined with specific substrates (especially peat moss-based substrate) was found to improve the growth of 'BRS Nagai' tomato seedlings. No toxic effects were observed. Further experiments aimed at testing concentrations of hydrogel will be required to estimate the beneficial effects on tomato seedling growth as 
well as to determine the adequate range of the copolymer dosages in order to avoid toxic side effects.

\section{ACKNOWLEDGEMENTS}

The authors thank Dourival Rodrigues Silva (Karlão) and Jorge de Lima (In memoriam) (Seeds laboratory); Kleyson Alves de Freitas and Guilherme Feitosa do Nascimento (interns) for their support during the realization of this work. Embrapa Hortaliças for the infrastructure and Embrapa Instrumentation for preparing and disposal of the hydrogel. Project CNPq 458763/2014-4, to CAPES (001 - PhD scolarship - Adriel Bortolin), to Rede Agronano, Sisnano/MCTIC and Finep.

\section{REFERENCES}

AKHTER, K; MAHMOOD, KA; MALIK, A; MARDAN, M; AHMAD, MMI. 2004. Effects of hydrogel amendment on water storage of sandy loam and loam soils and seedling growth of barley, wheat and chickpea. Plant, Soil and Environment 50: 463-469.

ANUPAMA, KR; SINGH, R; KUMAR, A; PARMAR, BS. 2007. Performance of a new superabsorbent polymer on seedling and post planting growth and water use pattern of chrysanthemum grown under controlled environment. Acta Horticulturae 724: 43-50.

BORTOLIN, A; SERAFIM, AR; AOUADA, FA; MATTOSO, LHC; RIBEIRO, C. 2016. Macro and micronutrient simultaneous slow release from highly swellable nanocomposite hydrogels. Journal of Agricultural and Food Chemistry 64: 3133-3140.

BRASIL. MAPA. 2009. Regras para análise de sementes. Brasília: Secretaria de Defesa Agropecuária. 399p.

CASTOLDI, R; TOLEDO, JA; DUARTE, WL. 2016. Eficiência da aplicação de hidrogel e lâminas de água no desenvolvimento de mudas de couve-flor. In: CONGRESSO BRASILEIRO DE OLERICULTURA, 54. Anais... Recife: ABH, p.168.
CONFEDERAÇÃO NACIONAL DA AGRICULTURA, 2017. Mapeamento e quantificação da cadeia produtiva das hortaliças do Brasil. Brasília, DF: 79 p. Available <http://www.cnabrasil.org.br/ sites/default/files/sites/default/files/uploads/ mapeamento_e_quantificacao_da_cadeia de_hortalicas.pdf $>$. Accessed March 8, 2018.

DU, J; CHEN, P; ADALATI, A; XU, S; WU, R; WANG, J; ZHANG, C. 2014. Preparation and mechanical properties of a transparent ionic nanocomposite hydrogel. Journal of Applied Polymer Science 21: 541-547.

EMBRAPA. 2014. Technological solutions and innovation: Embrapa in the international year of family farming. 107p.

FONTENO, WC; BILDERBACK, TE. 1993. Impact of hydrogel on physical properties of coarse-structured horticultural substrates. Journal of the American Society for Horticultural Science 118: 217-222.

FRANCHEMENT, M. 2012. Turnos de rega e doses de polímero hidrorretentor na formação de mudas de cafeeiro em tubetes e saquinhos. Lavras: UFLA, 46p. (M.Sc. dissertation).

GLOZER, K. 2008. Protocol for leaf image analysis - surface area. Available <http:// groups.ucanr.org/treecrop/files/58526.pdf > . Accessed on May 10, 2017.

GOMES, JM; COUTO, L; LEITE, HC; XAVIER, A; GARCIA, SLR. 2002. Parâmetros morfológicos na avaliação de qualidade de mudas de Eucalyptus grandis. Revista Árvore 26: 655-664.

GROSSNICKLE, SC. 2005. Importance of root growth in overcoming planting stress. New Forests 30: 273-294.

HEISKANEN, J. 1995. Physical properties of twocomponent growth media based on Sphagnum peat and their implications for plant-available water and aeration. Plant and Soil 172: 45-54.

JORGE, LAC; RODRIGUES, AFO. 2008. Safira: sistema de análise de fibras e raízes. São Carlos: Embrapa Instrumentação Agropecuária. 21p. (Boletim de pesquisa e desenvolvimento, 24).

JORGE, MHA; ANDRADE, RJA; COSTA, E. 2016. O mercado de mudas de hortaliças. In: NASCIMENTO, WM; PEREIRA RB (eds). Produção de mudas de hortaliças. $1^{\mathrm{a}}$ ed. Brasília: Embrapa, p.57-86.

LIMA, LML; TEODORO, REG; FERNANDES, DL; CARVALHO, HP; MENDONÇA, FC; CARVALHO, JOM. 2003. Produção de mudas de café sob diferentes lâminas de irrigação e doses de um polímero hidroabsorvente. Bioscience Journal 19: 27-30.

LUNA, AM; GARCÍA, ER; SERVÍN, JLC;
HERRERA, AL; ARELLANO, JS. 2014. Evaluation of different concentrations of nitrogen for tomato seedling production (Lycopersicon esculentum Mill.). Universal Journal of Agricultural Research 2: 305-312

MAHER, M; PRASAD, M; RAVIV, M. 2008. Organic soilless media components. In: Soilless Culture: Theory and Practice. RAVIV, M; LIETH, JH (eds). London: Elsevier. p.459-504.

NAKANO, Y. 2007. Response of tomato root systems to environmental stress under soilless culture. Japanese Agricultural Research Quarterly. 41: 7-15.

OZTEKIN, GB; GIUFFRIDA, F; TUZEL, Y; LEONARDI, C. 2009. Is the vigour of grafted tomato plants related to root characteristics? Journal of Food Agriculture and Environment 7: 364-368.

SABADINI, RC. 2015. Redes poliméricas de macromoléculas naturais como hidrogéis superabsorventes. São Carlos: UFSCAR. 150p (Ph.D. thesis).

SANCHES, LVC. 2013. Aplicação de polímero hidroretentor no desenvolvimento inicial de Eucalyptus grandis. Botucatu: UNESP. 97p (Ph.D. thesis).

SANTOS, HT; CARVALHO, DFS; CLAUDINEI, F; MEDICI, LO. 2015. Cultivo de alface em solos com hidrogel utilizando irrigação automatizada. Engenharia Agrícola 35: 852862.

SILVA, FAS; AZEVEDO, CAV. 2016. The Assistat Software Version 7.7 and its use in the analysis of experimental data. African Journal of Agricultural Research 11: 3733-3740.

SUCHOFF, DH; GUNTER, CC; LOUWS, FJ. 2017. Comparative analysis of root system morphology in tomato rootstocks. HortTechnology 27:319-324.

WANG, YT. 1992. Hydrophilic polymer and wetting agent had limited effect on growth and postproduction performance of Poinsettia. Subtropical Plant Science 45: 32-35.

WILLINGHAM, JR; COFFEY, DL. 1981. Influence of hydrophilic amended soil on growth of tomato transplants. Horticultural Sciences 16: 289-291.

WOFFORD JUNIOR, DJ. 1989. Use of crosslinked polyacrylamide in agriculture for increasing yield or reduce irrigation. Available $<$ https://www.hydrosource.com/use-of-crosslinked-polyacrylamide-in-agriculture-forincreasing-yield-or-reducing-irrigation/>. Accessed May 10, 2017. 